\title{
Politeness Speech on Solidarity Scale-Based Manado Malay Speakers
}

\author{
Thelma I. M. Wengkang*, Thomas M. Senduk \\ Fakultas Bahasa dan Seni, Universitas Negeri Manado, Indonesia \\ * thelmawengkang@yahoo.co.id, thomassenduk@yahoo.com
}

DOI: $10.20884 / 1 . j 1 i .2021 .12 .1 .3545$

\begin{abstract}
Article History:
First Received:

ABSTRACT

$25 / 11 / 2020$

Final Revision:

This study aims to describe the form and meaning of politeness speech on solidarity scale-based Manado Malay speakers. This study conducted in Manado city and used qualitative as a method. Observation and interviews

$17 / 05 / 2021$

Available online: were used as a technique of the study. The observation was used to observe the speakers of Manado Malay in using polite speech in daily social activities,

$30 / 06 / 2021$ whereas an interview was used by the researcher to questioning the informant about the use of polite speech in social interaction. This technique is complemented with listening, proficient, and note-taking techniques. The researcher plays a role as a key instrument who collects and analyzes the data. The source of data is the native speakers of Manado Malay who do interact in various places. Three informants who master Manado Malay were chosen. Techniques of analyzing data consist of 1) data reduction, simplified data collection, 2) data presentation, simplified data presented, categorized based on form and meaning, 3) verification, the data that has been presented were checked once more to ensure the accuracy according to the expected data, 4) conclusions, answering the predetermined problem formulations. The results showed that the social dimension, especially the solidarity scale, is a consideration for Manado Malay speakers in realizing polite speech, as well as when to use informal variants and when to use formal ones. The relationship among speakers has made them create the appropriate language choices, but language ethics that embody politeness remain a consideration. In various social interactions, occupations, religious meetings, associations, and family interactions, it turns out that Manado Malay people realize the politeness of speaking by changing command sentences into declarative sentences and asking along with the use of a flat intonation when speaking. The consideration of solidarity is the reason they speak politely, in addition to the status and formality scale.
\end{abstract}

Keywords: politeness speech; manado malay speakers; solidarity scale

\section{INTRODUCTION}

Language selection in the social interaction process is a common thing in a community that has many languages, especially in a heterogeneous community of ethnicity, culture, and language. 
This phenomenon happened in Manado city, which has a large number of different ethnicities, so using Manado Malay as a means of communication in various social events is the right choice. However, it does not mean they do not use other languages, most Manado people are bilingual. However, when it is seen from its intensity, Manado Malay is the most language widely used by Manado people. Ferguson in Ibrahim (1992) stated that speakers often use more than one language in one situation by using variations of that language in other situations.

The use of Manado Malay is very broad beyond other local languages in North Sulawesi. As emphasized by Ratu, Meruntu, and Palar (2018) that the use of Manado Malay has influenced other regional languages in North Sulawesi, such as in Minahasa and Bolaang Mongondow. In the area of North Nusa Tenggara, this language has penetrated remote areas of the village, so that it has become the language of association of young people. Even Tontemboan language, which has the largest number of native speakers, has been replaced by Manado Malay language. Polii in Kumayas (2021) stated that Tontemboan is one of the local languages in North Sulawesi, specifically in the region of Minahasa.

The sociolinguistic use of Manado Malay is very unique. Manado Malay speakers who live in Manado have a distinctive character. When they speak to each other, they choose harsh words occasionally in a high tone and speak plainly. Speakers are faced with various social contexts that encourage them to adapt. Ibrahim (1992) stated that in this case, speakers must choose which one should be used in certain situations.

Language selection is the best way to get out of communication deadlocks and confusion. Holmes and Wilson (1992) argued that there are four factors encouraging speakers to use language, (1) participants, with whom they speak, (2) social setting and context of interaction, where and in what situations they speak, (3) topics, what they talk about, and (4) function, why they spoke behind the speaker, and (5) the subject matter being discussed.

These four factors can explain the choice of language for speakers of Manado Malay. It is interesting to choose the language of people living in the city of Manado based on social dimensions as stated by Holmes and Wilson (1992), (1) social distance (solidarity), which is related to the relationship among speech participants, (2) status scale, which is related to status. inter-speech participants, (3) formality scales, related to the setting or type of interaction, and (4) functional scales, related to the goals or topics of the interaction. The scales provide a useful framework for discussing language in its social context in different speech communities and discussing how language reflects its users and assigned uses. Meruntu (2019) suggested that the social dimension is an important perspective that can explain the reasons for the choice of language for the Malay-speaking community in the city of Manado in interacting. 
The social dimension becomes a reference for speakers to speak in a variety of polite and harsh languages. Often encountered, speakers of Manado Malay speak very harshly, cursing at interlocutors, greeting the interlocutors with certain animal names or nicknames, and lacking language ethics. In fact, in certain contexts, this language attitude is considered something normal and acceptable, because it does not cause misunderstanding among speakers. This phenomenon shows that if the native speakers of Manado Malay have less understanding about politeness in speaking according to social dimensions. Sociopragmatically, politeness in speaking reflects language ethics. However, politeness in speaking is relative because it is related to the cultural characteristics and habits of the speakers. The form of politeness in speaking is realized from the intonation of speech, tone of voice, and context and utilizes declarative sentences and questions (Holmes \& Wilson, 1992). The politeness behavior, which is spoken by Manado Malay speakers, is interesting to be explored further from a sociolinguistic perspective and using social dimension tools based on a solidarity scale.

Holmes and Wilson (1992) stated that the solidarity scale or social distance is related to the social relationship among native speakers. The Solidarity scale is a dimension that influences speakers to choose speech variants in conversations. Therefore, this dimension is important, to see the relationship among speakers. This scale is very useful to emphasize that how much people know each other. This is a relevant factor in the linguistic choice. The use of declarative and interrogative sentences is often to be a consideration to show respect and avoid misunderstanding, compared to the use of imperative sentences. For example, here a short family conversation between a mother and her child:

Mother : Dik, ini kan sudah malam, mengapa belum mandi?

(Kid, it is late, why do not you take a shower?)

Anak $\quad$ : Iya bu, ini sudah mau ke kamar mandi.

(Yes mom, I am going to)

From the short conversation above, a mother tries to avoid the use of imperative sentences and replace it with an interrogative sentence. The mother tries to show her arrogant behavior to give a command. However, her purpose, which is well accepted by her child, is not only limited to verbal but also to action. These kinds of linguistic choices are common to be used by speakers in any social interaction.

This solidarity scale becomes a sociolinguistic instrument to explain the reasons and how does a native speaker realizes their politeness speech. These realized politeness speeches are often: 1) the choice of linguistic form such as the options of sentence form from imperative sentences to 
declarative and interrogative sentences, so its meaning turns into asking or requesting sentences, 2) the intonation, which is used as speaking, tries to avoid higher tone so it does not sound harsh and bark out, 3) the meaning behind the speech is sociopragmatic and semantically, it means that the meaning is being spoken as it is behind the speech. This politeness speech is used and chosen on purpose because the solidarity factor relates to the relation of friend, work, social status, and family.

This research is directed to describe the form and meaning of the politeness speech of Manado Malay speakers based on the scale of solidarity. Relevant researches to this one had been conducted by some researchers before. Ratu, Meruntu \& Palar (2018) conducted a research entitled Implikatur Pertanyaan Bahasa Melayu Manado (Implicature Question of Manado Malay). The difference between the mentioned research before and this research is in the field of study. Ratu, Meruntu \& Palar (2018) examined based on a pragmatic review, while this research used a sociolinguistic review. Next, Meruntu, Ratu \& Mumu (2019) conducted a research entitled Pilihan Bahasa Penutur Bahasa Melayu Manado Berdasarkan Dimensi Sosial (The Choice of language of Manado Malay's Native Speakers Based on Social Dimension). The difference of the mentioned research before and this research is the object of study, where they examined the choice of language of Manado Malay's native speakers based on the social dimension, while this research is only limited to the politeness speech of Manado Malay's speakers based on the scale of solidarity since this one is one of the scales of the social dimension.

\section{RESEARCH METHODOLOGY}

This research used the qualitative method. This method is used to describe systematically and deeply the form and meaning of politeness speech used by Manado Malay speakers living in Manado based on sociolinguistic reviews by utilizing social dimension theory, especially the solidarity scale. The location of this research was in Manado.

This research used observation and interview as a technique to collect the data. Observation used to observe Manado Malay speakers using polite language in their daily social activities. The researcher conducted the observations by mingling with various community groups to observe Manado Malay speakers use polite speech. The interview was conducted with informants about the use of politeness speech in social interactions. This technique was complemented by listening, proficient, and note-taking techniques. The researcher used data collection instruments such as observation paper and tape recorder. The source of the data is Manado Malay speakers who carry out interactions in various places and the informants who have been determined are three people who master Manado Malay. Analyzing data conducted jointly between forms and meanings of the 
speech, this technique proposed by Miles and Huberman (1992), 1) data reduction, the result data of observation and interview about the form and meaning of the politeness speech of Manado Malay speakers is transcripted, 2) data presentation, the simplified data is presented, categorized based on the form and meaning of the politeness speech which is used by the speakers of Manado Malay, 3) verification, the presented data is rechecked to ensure the data accuracy about the form and meaning of the politeness speech of Manado Malay speakers, 4) conclusions, to answer formulation of the problems about the form and meaning of the politeness speech of Manado Malay speakers.

\section{RESULTS}

\section{The Form of Politeness Speech of Manado Malay Speakers Based on Solidarity Scale}

In various social events, Manado Malay speakers use certain ways to convey something to the interlocutor. The solidarity scale becomes a reference for conveying something, for example refusing, asking, prohibiting, and ordering. It appears that in the ongoing conversation, speakers try to respect the interlocutor by using declarative sentences or questions so they sound polite, do not seem to command or yell because of the close relationship among speakers. The Solidarity scale is a consideration for using polite speech.

\section{The Politeness in Declarative Form}

The declarative sentence was deliberately chosen to refine the speech so it is seemed not bossy. Considering the following conversation. (Social context: Three men who work as masons are on their lunch break.)

T1 : So boleh stau kase pindah tu batu kalu mo pake.

(You might move the stones if you will use them.)

T2 : Sadiki le.

(A little bit more.)

T3 : Iyo katuk, baru makang le.

(Yeah right, just ate.)

T1 : Oh, iyo kang batu ada kaki mo bajalang sandiri.

(Oh, that's right; the stone has legs, so it can walk on its own.)

In the conversation above, $\mathrm{T} 1$ is known as the head mason who asked $\mathrm{T} 2$ to move the stones used for making the foundation. To make the speech sound polite or not bossy, T1 uses declarative sentences: So boleh stau kase pindah tu batu kalu mo pake. This sentence begins with so boleh 
stau so that it changes the form of this sentence into a declarative sentence. If you can remove the so boleh stau, then this sentence will change into a command sentence, namely Kase pindah jo tu batu mo pake! (Move the stones you'll be using!). Thus, the use of so boleh stau neutralizes the meaning of the sentence from ordering or yelling to asking or expect. The meaning of the sentence spoken by $\mathrm{T} 1$ is asking or expecting T1 to work again soon.

The conversation among three craftsmen that shows politeness is the T1 speech, Oh, that's right; the stone has legs, so it can walk on its own. This sentence is pronounced with a low intonation and a flat tone of voice. The form of this sentence is a declarative sentence, meaning a satire that tells a stone has legs, so it can move on its own. This sentence was deliberately spoken so that it sounded polite, not embarrassing T2, even though the actual meaning of this sentence was clear, namely ordering or asking $\mathrm{T} 2$ to immediately remove the stone referred to as $\mathrm{T} 1$.

The speech of T1, T2, and T3 how close their relationships are. The choice of using declarative sentences is better considered and acceptable to show respect in a working relationship. $\mathrm{T} 1$ tries to avoid arrogant behavior against $\mathrm{T} 2$ by using declarative sentences with meaningful asking, but the answer of $\mathrm{T} 2$ is not well accepted by $\mathrm{T} 1$, so the use of declarative sentences to insinuate is considered as the right choice to ask T2 to move the stones. From the choice of speeches among those speakers, it is revealed that how close each other are since they work together to build the construction. Since this consideration of solidarity, T1 tries to use polite speech to avoid offense with T2. Expressing something with insinuating to sound polite is one of the ordinary ways to be done by the native speakers of Manado Malay to avoid misunderstanding.

In other contexts, this solidarity scale also applies to family interactions between husband and wife or between parents and children. The use of Manado Malay spoken during family interactions has its peculiarities. Each family develops its communication patterns. For example, the way of parents greets their children by called the youngest brother and old brother. The greeting of parents towards this child is seen as more polite than calling their name. Consider the following conversation.

(Social context: One family consists of a father, mother, and two sons. The two boys play kites in the yard. It is cloudy and rainy)

Father

: Adek, kakak, so mo ujan.

(Kids, it will rain soon.)

Older Brother

: Blum kwak ujang.

(It hasn't rained yet.)

Younger Brother $\quad$ : (Memasuki Rumah), Papa, kakak blum maso.

([Entered home] Dad, brother does not enter yet.) 
The above conversation, in "adek, kakak, so mo ujan", the father greets the two boys with 'kakak' for the eldest son and 'adek' for the youngest one. The closeness between the father and his two children encourages the father to use the greetings "kakak" and "adek". This greeting is considered more subtle than addressing the eldest and youngest children by name. The meaning of the father's greeting to his two sons expresses a close loving relationship. The use of the sentence “adek, kakak, so mo ujan" (Younger and older brother, it will rain soon) shows the politeness of speaking to his two children and only tells that it will rain soon. The father's speech is accompanied by a low intonation and a flat tone, so it is more meaningful to tell, unlike the sentence "Papa, kakak blum maso!" (Dad, old brother doesn't enter yet!) This is an order.

In the context of socializing, politeness based on the scale of solidarity is also evident among young people. Considering the following conversation:

(Social context: Three girls of nearly the same age conversing.)

G1 : Bajalang kwak torang.

(Let's take a walk.)

G2 : Iyo, kwak so pastiu di rumah turus.

(Yes, I am tired of staying at home.)

G3 : Ngoni ndak tau kang tu saki virus corona di Manado so lebe banyak.

(You do not know that the number of positive cases of the corona virus in Manado is increased day by day.)

In the conversation above, G3 refuses G1 and G2's invitation to take a walk. G3 said a declarative sentence, "Ngoni ndak tau kang tu saki virus corona di Manado so lebe banyak". The form of the declarative sentence spoken by G3 is deliberately used to show politeness or respect in refusing the invitation of G1 and G2. G3 seems to only be stating information or informing that there are already a lot of corona virus sufferers in Manado. The meaning of G3's speech is clear, that she does not agree with the invitations of G1 and G2 or it means rejection. This speech in the form of a declarative sentence is deliberately used so that G1 and G2 are not offended. G3 here used an indirect speech to express disagreement with the invitations G1, and G2. The close solidarity relationship among the three girls made it possible for G3 to speak indirectly, the meaning of which was well understood by G1 and G2.

\section{The Politeness in Interrogative Form}

Using a question sentence to command or ask is a realization of politeness. The use of question sentences to refine the meanings of speech among speakers of Manado Malay is common. 
The dominant form of questioning used not only to command and ask but also sarcastically so as not to sound harsh. Considering the following conversation.

(Social context: The head of the sub-district gives greetings of grief at the funeral of one of the residents who died during social restrictions due to the spread of the corona virus in the city of Manado, while there are mourners who come not wearing masks.)

Lurah : Bapak, ibu, saudara-saudari, bole stau kang torang samua dalam acara seperti ini menggunakan masker?

(Ladies and gentlemen, brothers and sisters, is it okay, we all wear masks at events like this?)

In the discourse above, the Head of the Village deliberately used question, so as not to appear authoritative, especially when most of the mourners are elder. The speech of the village head shows a very high value of politeness, it is different when the head of the village says, Bapak, Ibu, Saudara-saudari torang samua dalam acara seperti ini harus pake masker! This form of the sentence is a form of command or order. The choice of the Lurah to use question sentences because of the solidarity relationship in which he as a leader, feels so close to the residents, the choice of interrogative sentences to invite is more appropriate than using command sentences. After all, choosing the form of the question is more appropriate because the context in which he spoke at that time is a grief event.

In another context in church hearings, the participants tried to avoid using a command sentence to say something. Considering the following conversation.

(Social context: A church council meeting is held routinely once a month. At that time there is an exchange of opinions among the congregation participants. The topic discussed is the continuation of the PAUD building construction.)

Ps : Bagimana Bapak, Ibu, Apa pembangunan gedung PAUD torang so mo kase turus.

(Ladies and Gentlemen, what if this PAUD building continues to construct?

P1 : Apa ndak, lebe bae, pembangunan gedung PAUD torang tunda dulu, karena kondisi bulum memungkinkan?

(It will be better if we postponed the construction of the PAUD building first because the conditions were not yet favorable?)

P2 : Kalu kita, begitu stau sama deng P1 pe pendapat. Bagimana torang membangun sedang jemaat skarang merasa susah karena corona?

(I'm the same as the opinion of P1. How do we build while the congregation is currently feeling distressed because of the pandemic? 
In the conversation above, code-mixing occurred when the participants express their opinions. P1 and P2 used the interrogative sentence form to express their disapproval of continuing the PAUD building construction. P1 deliberately used the question to express his disagreement with the plan to continue the construction of the PAUD building, so that it sounded smooth or polite, especially when the context of speaking at that time was in the church building and the congregation leader faced was a pastor. Likewise, P2 has done the same, using a question to express his disagreement with the PAUD building construction plan. The refiners of speech intent are indicated by the use of lebe bae by $\mathrm{P} 1$ and thus by $\mathrm{P} 2$. However, the question phrase used by P1 and P2 has a clear meaning, rejection or disapproval.

In family interactions, this question sentence is also often used by parents to advise children. The question sentence was chosen to avoid the child's drifting off, which could lead to misunderstanding. Considering the following conversation.

(Social context: A mother advises her teenage son not to leave the house often because of the spread of the corona virus in the city of Manado.)

A : : Mak, kita mo kaluar mo pi pa taman pe rumah ndak lama.

(Mom, I want to go to a friend's house, just for a moment.)

I $\quad$ : Dek, ngana nyandak dengar so di brita tu tajangke virus corona tatambah?

(Son, you did not hear the news, the number of people infected with the corona virus has increased?

A : Iyo, kwak mak kita le tau!

(Yes mom, I knew)

The conversation above shows the close solidarity relationship between I as a mother and A as a child. The mother responded that A's desire to go to a friend's house gave information that the number of people infected with the corona virus in Manado is increased. Because of the close relationship, I did not use words of command or prohibition to tell his son not to go to a friend's house. The affirmation of intent in the form of an interrogative sentence is indicated by the use of the particle so. The real meaning of this question sentence is not to tell, but the meaning of expressing rejection or disapproval. The mother chooses indirect speech to give advice so that her child does not get angry. It is different if the mother says, using the sentence "Jangan pigi ke rumah teman, nanti ta jangke virus corona" (Do not go to a friend's house, you will be infected by Corona virus). The prohibited sentence used by a mother can make her child angry.

Polite speech based on the solidarity scale is also realized in the conversation between the servant and the employer. Based on the status of the relationship between employer and servant, 
it realizes a relationship between people with higher social status and people with lower social status. However, considerations of solidarity and ethics encourage employers to use polite speech to show respect to their servants. Consider the following conversation.

(Social context: A husband and wife who work as civil servants require them to use a maid to care for a toddler. The servant is older than the employer. One afternoon the female employer came home from work and had a conversation with the maid.)

M : Adek masih tidor dang?

(the kid is still sleeping huh?)

$\mathrm{P} \quad$ : Iyo, baru, so lelah bermaeng.

(Yes, just now, he is tired of playing.)

M : Kita da singgah pi pasar dabilih ikang.

(We stopped at the market to buy fish.)

$\mathrm{P} \quad$ : Oh, iyo, kita goreng jo tarek, mar kotek abis minyak kalapa.

(Oh, yes, I will fry it, but the coconut oil runs out.)

M : Boleh jo kwak tanta Atik pi bilih akang di warong?

(Can aunt Atik go to the shop?)

$\mathrm{P} \quad$ : Iyo!

(I can)

In the conversation above, it appears that the employer realizes polite speech to the servant. The polite speech is marked by the use of the greeting "Tanta Atik" (Mrs. Atik) and the choice of sentences to order or gives orders is realized with the question "Boleh jo kwak tanta Atik pi bilih akang di warong? This sentence is deliberately used by the employer (M) to show respect for his older servants so that they do not appear to be commanding. The sentence of the question is marked with the use of "boleh jo kwak" (may you), so the meaning changes to ask or beg.

\section{DISCUSSION}

Speech expressing politeness is a language behavior commonly used by Manado Malay speakers in various social interaction events. Manado Malay which seems harsh and straightforward is not the case, because it turns out that politeness in speaking is often a consideration because of the relationship of solidarity. For example, in a particular speech, the speaker avoids on purpose the use of imperative sentences and changes with the declarative sentence. The use of imperative sentences often is interpreted as arrogance, on the contrary, the use of declarative sentence for command means showing respect. The use of so boleh (could you) refines the meaning to become asking and offering. The use of this form becomes an option for 
Manado Malay speakers to express something in various social events. This is to show solidarity. The realization appeared in the conversation of workers who are working to build a building.

The appeared phenomenon shows that politeness speech is realized into diction to greet someone. The use of greeting words kakak and adek are common calls used by parents to their children, kakak is for the elder brother or sister and adek is for the younger brother or sister. Speakers often refine speech to make it more polite by choosing declarative and interrogative sentences instead of using imperative sentences. The research findings reveal that the social dimension, especially the solidarity scale, is an important consideration in using language choice. In line with these findings, Holmes and Wilson (1992) described the social scale as providing a useful framework for discussing language in the social context of different speech communities and discusses ways of language reflecting agreed users. Social distance (solidarity) is a scale that encourages Manado people to select the language when interacting. The scale of solidarity considers when to use a coarse variety and when to use a subtle variety. Relationship among speakers makes speakers choose the appropriate language, but language ethics that embody politeness remain a consideration. This finding can be compared to research conducted by Meruntu (2019), which stated that the relation among speakers makes speakers choose an appropriate speech, for example, in calling or mentioning someone's name. The word kadok can be matched to other words kadas, kudis, kurap. In English translation, those are skin diseases which zap animals like dog and pig, but those words can be used to greet someone. The word choice of kadok is a harsh word, however, the close social distance among speakers who have the same age, will not cause problems. The same thoughts are supported by the research conducted by Pengemanan, Wantalangi, and Mauru (2018) entitled Sapaan Bahasa Melayu Manado di Kalangan Anak Muda. From the study, naturally, there are agreements among millennials to use the greetings in Manado Malay. Any speeches that sound harsh and impolite to other languages native speakers are ordinary and acceptable. Calling someone with an animal is normal thing.

In various social interactions, occupations, religious meetings, associations, and family interactions, the speakers of Manado Malay understand the need to manifest politeness in speaking by changing command sentences into declarative sentences and asking questions accompanied by the use of a flat intonation when speaking. This is as emphasized by Holmes and Wilson (1992) that the form of politeness in speaking is manifested from the intonation of speech, tone of voice, and context and utilizes declarative sentences and questions. The reasons for polite speech are manifested during the conversation is to show respect, humility, and avoid offending each other, which makes communication disrupted. From a pragmatic review, the realization of politeness 
may be mere lip service or not based on sincerity, as stated by Leech (1993). However, considerations of solidarity are the reasons for Manado Malay speakers to speak politely, in addition to the scale of status and formality.

\section{CONCLUSION}

From the results, it can be concluded that the social dimension, especially the solidarity scale, is a consideration for Manado Malay speakers in realizing politeness speech. The scale of solidarity considers when to use a coarse variety and when to use a subtle variety. Relationship among speakers makes speakers choose the appropriate language, but language ethics that embody politeness remain a consideration. In various social interactions, occupations, religious meetings, associations, and family interactions. The speakers of Manado Malay understand the need to manifest politeness in speaking by changing command sentences into declarative sentences and asking questions accompanied by the use of a flat intonation when speaking. The consideration of solidarity is the reason Manado Malay speakers speak politely, in addition to the status and formality scale.

\section{ACKNOWLEDGEMENT}

We thank our colleagues from the Indonesian Education and Arts Department (JPBSI UNIMA) who provided insight and expertise that greatly assisted the research. Also, for their responses who support the research. We are also immensely grateful to all respondents for their responses.

\section{REFERENCES}

Agustina, R. A., Juita, N. (2019). Kesantunan Berbahasa Pembawa Acara Waktu Indonesia Timur di Net TV. Jurnal Bahasa dan Sastra, 6 (3), 422-434. DOI: https://doi.org/10.24036/81037370.

Andari, S. D. (2017). Prinsip Kesantunan dalam Curahan Hati Perempuan di Trans TV Episode Juni 2016. Jurnal Pembahsi: Pembelajaran Bahasa dan Sastra Indonesia, 7 (1), 43-54 .DOI: http://dx.doi.org/10.31851/pembahsi.v7i1.1283

Ardi, H., Nababan., Djatmika., Santosa, R. (2016). Politeness Strategy in Indonesian Translation: Has it Already Changed?. Prosiding Prasasti. Retrieved From: https://jurnal.uns.ac.id/prosidingprasasti/article/view/1536. DOI: https://doi.org/10.20961/pras.v0i0.1536.

Holmes, J., \& Wilson, N. (1992. An Introduction to Sociolinguistics. New York: Longman.

Ibrahim, S. (1992). Sosiolinguistik, Sajian, Tujuan, Pendekatan dan Problem. Surabaya: Usaha Nasional. 
Junaidi, M. (2017). Politeness, Speech Act, and Discourse In Sasak Community. Mabasan Journal, Vol. 11 (1): 1-17. DOI: https://doi.org/10.26499/mab.v11i1.48.

Kumayas, T. (2021). Tontemboan Affixes: Notes in Teaching English Tenses. International Journal of Applied Business and International (IJABIM), 6 (1), 101-109.

Leech, G. (1993). The principles of pragmatics [M. D. D. Oka, Tran]. Jakarta: UI Press.

Miles, M. B., \& Huberman, A. M. (1992). Qualitative data analysis [T. R. Rohidi \& Mulyarto, Trans]. Jakarta: UI Press.

Meruntu, O. S., Ratu, D. M., \& Mumu S. E. (2019). Language option used by communities Manado service language writing based on social Dimensions. Advances in Social Science, Educational and Humanities Research, 383, 810-815.

Mutiara, F. R., Rokhman, F. (2019). Politeness Principle Obedience on Governor and Vice Governor's Utterances in the "Kandidat Bicara Talk Show". Seloka: Jurnal Pendidikan Bahasa dan Sastra Indonesia, 8 (3), 8-14. DOI: 10.15294/SELOKA.V8I3.34403.

Pengemanan, N. J., Wantalangi, M., \& Mauru G. (2018). Address Terms Among the Young Male Speakers of Manado Malay in Manado City. Advances in Social Science, Educational and Humanities Research, 226, 864-868.

Ratu, D. M., Meruntu, O. S., \& Palar, W. R. (2018). Pragmatic Implicature of Manado Malay Question. Advances in Social Science, Educational and Humanities Research, 226, 908-912.

Rukhana. F, Andayani., Winarni, R. (2018). The Adherence Form of Linguistic Politeness in Learning Indonesian for Foreign Speakers. International Journal of Multicultural and Multireligious Understanding, 5 (6), 73-80. DOI: http://dx.doi.org/10.18415/ijmmu.v5i6.469. 